\title{
HOW AGASSIZ TAUGHT PROFESSOR WILDER ${ }^{1}$
}

7 WE phrase adopted as the title of this article ['Louis Agassiz, Teacher'] begins his simple will. Agassiz was likewise an investigator, a director of research, and the founder of a great museum. He really was four men in one. Without detracting from the extent and value of the three other elements of his intense and composite American lifefrom his first course of lectures before the Lowell Institute in $\mathbf{1 8 4 6}$ to the inauguration of the Anderson Summer School of Natural History at Penikese Island, July 8, 1873, and his address before the Massachusetts State Board of Agriculture, twelve days before his untimely death on December 14, 1873,-Agassiz was

1 From an article by Professor Burt G. Wilder, of Cornell University, in The Haroand Graduales' Magazine, June, 1907. The extract is taken from a reprint with slight changes by the author, and is given with slight omissions by the present oriter. 
pre-eminently a teacher. He taught his assistants; he taught the teachers in the public schools; he taught college students; he taught the public, and the common people heard him gladly. His unparalleled achievements as an instructor are thus chronicled by his wife:

'A teacher in the widest sense, he sought and found his pupils in every class. But in America for the first time did he come into contact with the general mass of the people on this common ground, and it influenced strongly his final resolve to remain in this country. Indeed the secret of his greatest power was to be found in the sympathetic, human side of his character. Out of his broad humanity grew the genial personal influence by which he awakened the enthusiasm of his audiences for unwonted themes, inspired his students to disinterested services like his own, delighted children in the school-room, and won the cordial interest, as well as the co-operation in the higher aims of science, of all classes, whether rich or poor.'

As a general statement the foregoing could not be improved. But the invitation to prepare this article contained a suggestion of par[32] 
ticularity with which it is possible for me to comply. ${ }^{2}$ The courses given by Agassiz on zoology and geology were attended by me during the three years (1859-62) of my pupilage with Jeffries Wyman, and the two years (1866-68) in which I was the assistant of Agassiz himself. Naturally, and also for special reasons, the deepest impression was made by the first and the last of these courses. With the former the charm of novelty intensified the great, indeed indescribable, charm of the speaker. No topic was to me so important as the general problem of animal life, and no expositor could compare with Agassiz. As an outlet for my enthusiasm each discourse was repeated, to the best of my ability, for the benefit of my companion, James Herbert Morse, '63, on the daily four-mile walk between Cambridge and our Brookline home. So sure was I that all the statements of Agassiz were correct and all his conclusions sound, that any doubts or

2 Not only have I preserved all the letters from Agassiz, the first dated Sept. 4, 1866, and the last Nov. 25, 1873, but also my diaries in which are recorded all significant incidents and conversations from my first introduction in 1856 to the last interview, Sept. 5, 1873. [Note by Professor Wilder.] 
criticisms upon the part of my acute and unprejudiced friend shocked me as a reprehensible compound of heresy and lese-majesty.

The last course that $I$ heard from Agassiz in Cambridge began on October 23, 1867, and closed on January 11, 1868. It was memorable for him and for me. At the outset he announced that some progress had been made in the University toward the adoption of an elective system for the students, and that he proposed to apply the principle to his own instruction, and should devote the entire course of twenty-one lectures to the Selachians (sharks and rays), a group in which he had been deeply interested for many years, and upon which he was then preparing a volume. This limitation to a favorite topic inspired him to unusual energy and eloquence. My notes are quite full, but I now wish the lectures had been reported verbatim. This course was signalized also by two special innovations, viz.: the exhibition of living fish, and the free use of museum specimens. That, so far as possible, all biologic instruction should be objective was with Agassiz an educational dogma, and upon [34] 
several notable occasions its validity had been demonstrated under very unfavorable conditions. Yet, during the five years of $\mathrm{my}$ attendance upon his lectures, they were seldom illustrated otherwise than by his ready and graphic blackboard drawings. The simple fact. was that the intervals between his lectures were so crowded with multifarious, pressing, and never-ending demands upon his time and strength that he could seldom determine upon the precise subject long enough in advance for him, or any one else, to bring together the desirable specimens or even charts. The second lecture of the course already mentioned is characterized in my diary as 'splendid,' and as 'for the first time illustrated with many specimens.' At one of the later lectures, after speaking about fifteen minutes, he invited his hearers to examine living salmon embryos under his direction at one table, and living shark embryos under mine at another.

Like those of Wyman, the courses given by Agassiz were Senior electives. I never heard of any examination upon them; nor is it easy to imagine Agassiz as preparing a syllabus, or 
formulating or correcting an examinationpaper. His personality and the invariable attendance of teachers and other adults precluded the necessity of disciplinary measures. But his attitude toward student misconduct was clearly shown in an incident recorded by me elsewhere. ${ }^{1}$ The method pursued by Agassiz with his laboratory students has been described by Scudder. ${ }^{2}$ Although I was to prepare specimens at his personal expense, a somewhat similar test was applied. He placed before me a dozen young 'acanths' (dog-fish sharks), telling me to find out what I could about them. After three days he gave me other specimens, saying: 'When you go back to the little sharks you will know more about them than if you kept on with them now'-meaning, I suppose, that I should then have gained a better perspective.

Although, as I recall upon several occasions, Agassiz could express his views delightfully and impressively to a single auditor, his emi-

1 'Agassiz at Penikese,' American Naturalist, March, 1898, p. 194. [Note by Professor Wilder.]

${ }^{2}$ See below, p. 40.

[36] 
nently social nature and his lifelong habit rendered it easier for him to address a group of interested listeners. The following incident does not seem to have been recorded in my diary, but it is distinctly remembered. During the publication of the Journey in Brazil, a French translation was made by $M$. Félix Vogeli. With this the publishers desired to incorporate a chapter giving the latest views of Agassiz upon classification and evolution. In vain was he besought to write it. He hated writing, and was too busy. At last, in desperation, M. Vogeli came to the Museum with Mrs. Agassiz, and together they persuaded the Professor to dictate the required matter in the form of a lecture. For this, however, an audience was indispensable. The exigency was explained to the Museum staff; we assembled in the lecture-room, and the discourse began. To the dismay of some of us it proved to be in French, but we tried to look as if we comprehended it all.

Agassiz handled all specimens with the greatest care, and naturally had little patience with clumsiness; the following incident illustrates 
both his kindly spirit and his self-restraint. At one of the lectures he had handed down for inspection a very rare and costly fossil, from the coal-measures, I think; including the matrix, it had about the size and shape of the palm of the hand. He cautioned us not to drop it. When it had reached about the middle of the audience a crash was heard. The precious thing had been dropped by a new and somewhat uncouth assistant whom we will call Dr. X. He hastily gathered up the pieces and rushed out of the room. For a few seconds Agassiz stood as if himself petrified; then, without even an 'Excuse me,' he vanished by the same door. Presently he returned, flushed, gazing ruefully at the fragments in his hand, covered with mucilage or liquid glue. After a pause, during which those who knew him not awaited an explosive denunciation of gaucherie, Agassiz said quietly: 'In Natural History it is not enough to know how to study specimens; it is also necessary to know how to handle them' -and then proceeded with his lecture.

His helpful attitude toward prospective teachers was exhibited in the following incidents.

[38] 
After my appointment to Cornell University in October, 1867, he arranged for me to give a course of six 'University Lectures,' and warned me to prepare for them carefully, because he should give me a 'raking down.' He attended them all (at what interruption of his own work I realize better now), and discussed them and my methods very frankly with me. Omitting the commendations, the following comments may be useful to other professorial tyros: 1. The main question or thesis should be stated clearly and concisely at the outset, without compelling the hearer to perform all the mental operations that have led the speaker to his own standpoint. 2. In dealing with the history of a subject, the value of each successive contribution should be estimated in the light of the knowledge at the period, not of that at the present time. 